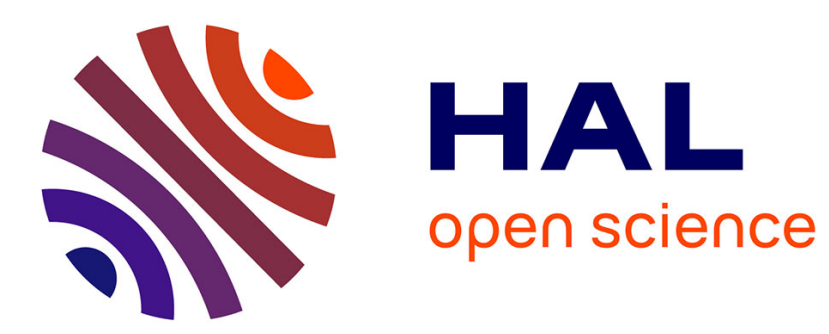

\title{
Wine brands or branded wines? The specificity of the French market in terms of the brand
}

Catherine Viot, Juliette Passebois-Ducros

\section{To cite this version:}

Catherine Viot, Juliette Passebois-Ducros. Wine brands or branded wines? The specificity of the French market in terms of the brand. International Journal of Wine Business Research, 2010, 22 (4), pp.406-422. 10.1108/17511061011092438 . hal-01803728

\section{HAL Id: hal-01803728 \\ https://hal.science/hal-01803728}

Submitted on 31 May 2018

HAL is a multi-disciplinary open access archive for the deposit and dissemination of scientific research documents, whether they are published or not. The documents may come from teaching and research institutions in France or abroad, or from public or private research centers.
L'archive ouverte pluridisciplinaire HAL, est destinée au dépôt et à la diffusion de documents scientifiques de niveau recherche, publiés ou non, émanant des établissements d'enseignement et de recherche français ou étrangers, des laboratoires publics ou privés. 


\section{WINE BRANDS OR BRANDED WINES? \\ THE SPECIFICITY OF THE FRENCH MARKET IN TERMS OF THE BRAND \\ Catherine Viot \\ Maître de Conférences \\ Institut d'Administration des Entreprises \\ 35, Avenue Abadie \\ 33072 BORDEAUX cedex \\ France \\ catherine.viot@u-bordeaux.fr \\ $33(0) 556009705$ \\ Equipe de Recherche en Marketing de l'IRGO \\ Université Montesquieu - Bordeaux IV}

Research Fellow to the E-commerce and Retail chair of BEM Bordeaux Management School

Juliette Passebois- Ducros

Maître de Conférences

Institut d'Administration des Entreprises

35, Avenue Abadie

33072 BORDEAUX cedex

France

$33(0) 556009690$

Equipe de Recherche en Marketing de l'IRGO

Université Montesquieu - Bordeaux IV

Viot C, Passebois-Ducros J. (2010), Wine brands or branded wines? The specificity of the French market in terms of the brand. International Journal of Wine Business Research, 2010, 22 (4), pp.406-422. $\langle 10.1108 / 17511061011092438\rangle$. 


\title{
WINE BRANDS OR BRANDED WINES? THE SPECIFICITY OF THE FRENCH MARKET IN TERMS OF THE BRAND
}

\begin{abstract}
Purpose - The purpose of this article is to show that the branded wine concept refers to a very heterogeneous category as regards wine made in France, but this sort of wine can appeal to certain types of consumers.

Design/methodology/approach - An initial qualitative study was carried out to explore consumer representation as regards branded wine. A second, quantitative, study enabled us, through a cluster analysis, to identify brand-sensitive consumer segments in the wine field.

Findings - There is a divergence in consumer representation between novices and experts. The former consider A.O.C.s (Appellation d'Origine Contrôlée, a French official label of protected geographical indication) and regions as brands whilst the latter have a narrower vision of what a branded wine means. The "discoverers", the youngest consumers (18-29 years old), who are interested in wine and have little knowledge of it are most liable to be influenced by wine brands. The novices and routine consumers are also brand sensitive but to a lesser degree. The experts, on the other hand, are not influenced by brands.

Research limitations/implications - The influence of the brand derives from the declarative. A more indirect measure which mixes the brand with other wine attributes would be preferable. The use of a sample of convenience means results can only be generalized with caution.
\end{abstract}

Practical implications - There indeed exists a place for branded wines on the French market but an association is needed with other attributes such as the origin and/or the grape variety.

Originality/value - Little research has been devoted to the French consumer's acceptance of branded wines.

Keywords: Brand Equity, wine brands, branded wines, involvement, subjective knowledge Paper type: Research Paper

\section{Introduction}

In France, regular consumption of wine is declining and is being replaced by more occasional consumption which is more closely focused on immediate pleasure and quality at a reasonable price. In the face of such an obvious statement of fact, certain producers have adapted their production in accordance with the wishes of these new, non-traditional consumers. Individual or collective marketing strategies have been put into place and have been translated into: new brands; new packaging (cans, bags in box and 25cl); new labels which break with traditional codes and new ways of selling (sales by Internet for example).

Among the various initiatives being taken one appears to stand out: the development of a brand strategy. The major wines and spirits groups embarked on this strategy a long time ago since it has enabled them to simplify what they offer to the consumer and provide the latter with a product whose quality stays constant. The Baron Philippe de Rothschild group were the first in France when they launched the Mouton Cadet brand, a mythical brand from the 1930s, which capitalized on the renown of Château Mouton Rothschild. Wine merchants rapidly followed this strategy by developing their own brands and using their commercial power to ensure their success (for example JP Chenet, Grand Chaix de France group; Baron de Lestac, Castel group). Today, several trade syndicates also develop their brands (Le flacon, Cotes de Bourg; e-motifs, Bordeaux supérieur), as do retailers (Pierre Chanau, Auchan) and a few small producers ( $l$ ' $R$ de rien by François de Ligneris). The brand notion, therefore, does not reflect a single coherent entity in the wine field as much as it refers to different production methods (blending in certain cases, production from a single estate in others) and therefore variable quality levels. As a result, the brand notion is not clear in 
consumers' minds: Eight French consumers out of ten cannot give a correct name of a wine brand, $60 \%$ of them give the name of a terroir or a château when they are asked to name a brand (ONIVINS, 2003). Despite this poor knowledge, certain wine brands achieve record sales every year (36 million bottles in 2005 for Vieux Pape, 90 million bottles for JP Chenet in 2004) which is a proof of the substantial potential which characterizes this type of strategy.

The prime objective of this article is to clarify the brand notion when it is applied to wine in the French context. The article also aims to understand the scope of its influence on consumers' behaviour and identify possible groups of consumers for whom the brand plays an important role.

A review of the literature will highlight the necessary adaptation of the brand concept as regards wines' product category as well as the role that the brand can potentially play in the wine-purchasing process. A qualitative study will help to clarify the brand concept. It will be followed by a quantitative one whose aim is to identify brand-sensitive consumers in the field of wine. After these developments, we will discuss the interest the players have in embarking on strategies aimed at developing branded wines.

\section{Theoretical background}

The brand is defined as "a name, term, sign, symbol, or design, or a combination of these, intended to identify the goods or services of one seller or group of sellers and to differentiate them from those of competitors" (American Marketing Association). According to numerous scholars, the pure and simple transposition of this generic definition is problematic as regards wine (Boulet and Laporte, 1997; D'Hauteville, 2004; Sirieix, 2001). We therefore put forward a specific notion of the wine brand: "a wine brand is a cluster of attributes which defines the identity of the wine in the eyes of the buyer" (Lockshin, 2004). This 'brand constellation' notion, despite its interest, does not constitute a wine brand definition in itself for it allows us neither to clearly define the outline nor to classify the different branded wines found on the market. Moreover, many empirical studies carried out in Australia, the United States and Europe show that the brand, as an attribute, has varied degrees of importance (Table I). For the Australian consumer, the brand is only mentioned in fourth position, even though "marketed" wines are widespread in Australia (Aurifeille et al., 1999; Quester and Smart, 1996; Rasmussen and Lockshin, 1999). In the United States, the brand is found in third position although the grape variety is the most important attribute (Zaichkowsky, 1985). For the Irish, the brand is placed in second position, just after the country of origin. (Koewn and Casey, 1995). The manner in which the French consumer chooses between different wine attributes is still unknown.

Table I - Wine attributes importance in different countries

\begin{tabular}{cccc}
\hline $\begin{array}{c}\text { Australia } \\
\text { Rasmussen and } \\
\text { Lockshin (1999) }\end{array}$ & $\begin{array}{c}\text { Australia } \\
\text { Aurifeille et al. } \\
(1999)\end{array}$ & $\begin{array}{c}\text { The United States } \\
\text { Zaichoswsky } \\
(1988)\end{array}$ & $\begin{array}{c}\text { Northern Ireland } \\
\text { Koewn andt Casey } \\
(1995)\end{array}$ \\
\hline Price & Taste & Grape variety & Country of origin \\
\hline Taste & Price & Vintage & Brand \\
\hline Origin (region) & Type of wine & Brand & Grape variety \\
\hline Brand & Brand & Country of origin & Origin (region) \\
\hline Style, Grape variety & Label, Packaging & Price & alcohol content \\
\hline Label & $\begin{array}{c}\text { Others (alcohol } \\
\text { content, region, age } \\
\text { and colour) }\end{array}$ & Others & Classifications \\
& & & \\
\hline
\end{tabular}


But, if the power of the brand attribute is established in literature, only "strong" brands could have such an effect on consumer behaviour. The brand strength is conceptualized by the brand equity construct. Brand equity is determined by brand awareness, perceived quality, consumers' loyalty and brand associations or brand image (Aaker, 1996). For the French market, what we usually consider as a brand for the other products categories is not necessarily associated with a strong brand when it concerns wine, although there are some exceptions like Mouton Cadet, Baron de Lestac... Some of them suffer from a lack of awareness and/or their perceived quality is not very high. They are often associated to downmarket wines like La Villageoise, a wine sold in plastic bottles.

\section{Conceptual model and research propositions}

From the consumer's point of view, the brand acts as a heuristic of choice, as a risk limiter according to Roselius (1971) and Jakoby and Kaplan (1972) and as a sign of quality which gives consumers an indication of the quality of the product prior to consumption and/or helps consumers to remember a level of quality associated with a product they have already consumed. A sign of quality is: "an information summary (an overall knowledge or a concentration of learning) that is reinforced by product display, or a family of products, from a signal allowing consumers to identify and recognize the product: a logo, a symbol, a name, etc." (Mazé et al., 2001). By replacing other information, the brand simplifies the selection process. In the food industry, the requirement for quality means that the brand notion - seen as a sign of quality - is a first-rate strategic asset (Belik, dos Santos and Green, 2001). However, the brand notion applied to wine remains ambiguous for certain consumers. They do not possess a clear perception of what a branded wine is. Specifically, consumers tend to infer the same status to generic types - grape and region - as they do to specific brands (Gluckman, 1990). Certain regions or certain terroirs in France (Bordeaux, Alsace, Provence, Languedoc, Burgundy, etc.) take the role of the brand both for the foreign consumer (Mora, 2008, p. 21) and for the domestic one (Boulet and Laporte, 1997; Gluckman, 1990; Holter, 1996). Nevertheless, it is at best a generic brand whose identity is not necessarily very clear since it is the result of a very high number of producers (more than 10,000 for Bordeaux alone). On the other hand, for the New World, the approach is different: the consumer buys a grape variety (Cabernet Sauvignon), a brand (Casillero del Diablo) or the name of a company (Mondavi). In the last instance, the brand masks an extremely wide variety of origins: for example, Mondavi buys wine in Italy and Chile and sells it under a single brand name. In Australia, only involved consumers are considering region of origin as an important choice factor in the wine-buying decision making process (Mc Cutcheron, Bruwer and Li, 2009).

The legal point of view strengthens the complexity of French regulations on viti-vinicultural brands. For example, to be registered as a brand, the sign in question must be distinctive - it must not be the necessary, generic or usual designation of the product - and non-deceptive not mislead the public on the nature, quality or geographical origin of the product - (articles 711-1 and following of the Code of Intellectual Property). Once these legal provisions have been respected, the company has a wide choice as regards the creation of a brand name. A place-name (name of a château, a hamlet) can be registered as a brand on condition that it indeed corresponds to the vineyard in question (Château Haut-Brion, Petrus). Only A.O.C. wines can use the terms "clos (walled vineyard), château, domaine, tour (tower), mont, côte (hillside)". However, local wines can mention the geographical origin since they are produced in a one and the same "pays" (a département or a terroir : Vin du Pays d'Oc, for example) and furthermore they can add qualitative terms such as «mas» (traditional farmhouse) or "domaine", considered as more characteristic of the country than the term "château". On the other hand, this is not possible for table wines. The name of the owner can be established as a 
brand (Château Lynch-Bages). Finally, the brand can be unconventional (Mouton Cadet). The name of the brand cannot refer to an A.O.C.. As such, the brands Domaine de la Romanée Conti, Fort Médoc or Vieux Cahors were removed since they included a name of an A.O.C. in their denomination. A few exceptions to this principle exist: Bouquet de Provence (the brand name existed before the Cotes de Provence 'appellation') and Chateau Grillet, which is both the name of a château and an A.O.C., for example. French law therefore makes a very clear distinction between a brand and an A.O.C.. This legal wide conception as regards the creation of wine brands could entail a bigger confusion in consumers' mind.

Finally, from the producer point of view, the notion of brand wine is confusing. Thousands of labels and operators are present on wine market and most of them are emerging from relatively small and family businesses. All of these brands cannot be considered as real "wine brands" because these small producers cannot offer themselves the powerful tools of advertising and promotion indispensable to build mass market awareness and brand equity. More precisely, a survey of the managerial practices reveals that the French commercial environment is characterized by three major types of brand strategy.

The first, the "merchant brand", corresponds to wines sold by merchants (Bomsel, 2003, quoted by Gherbi, 2004) such as Malesan, Baron de Lestac, Celliers des dauphins, J. P. Chenet etc. These are generally blended wines. It is a wine which is made, bottled and packaged by a merchant who puts his/her own name and brand on the label. It is characterized by the fact that it guarantees a result to the consumer - the quality is constant - and by the fact that the product has been made to suit the market.

For the second - the "producer brand" - the production process is the central element: it guarantees a striving for quality, a means of production dedicated to obtaining a "good wine" and the origin (Bomsel, 2003). This category includes, for example, château wines. Any wine estate with the means to grow vines and make wine can take the name of a château and sell its wine under this name as long as it is an A.O.C..

The third type includes wine sold under a store's brand. These brands have an important place in France since they accounted for more than $32 \%$ of sales in large and medium-sized retail outlets in 2007, which represents 6 points growth compared to 1998 (Viniflhor, 2008a). In fact, this category covers clearly distinct strategies (Gherbi, 2004). The case of a retailer's brand name being displayed on the label remains relatively rare since consumers are not always prepared to show a wine carrying a retailer's logo at their table (for example, wines from Leader Price, a hard discounter). Reserved brands are wines bottled exclusively for a retailer (Pierre Chanau, Auchan's own brand). The brand is only available in the outlets of a single retailer but the same wine can be distributed by a competitor under a different name. "Reference" brands serve as a discreet reminder of the retailer's name (La sélection Auchan) through the use of a fixed neck-band label.

In conclusion, branded wines, on the French market, refer to a very heterogeneous category of wines, especially as regards production methods. The existence of different conceptions of brand, the strong reputation of some AOC and the various brand strategies followed by wine producers and wine merchants are quite confusing for consumers while we can suppose that it will not be the case for experts, in particular for people working in the wine sector. That's why we formulate a first research proposition $\mathrm{P}_{1}$ :

\section{$P_{1}$. In the field of wine, the representation of brand will differ between experts and consumers.}

\section{The moderating role of involvement}

The wine-buying process is influenced by several personal variables among which we find involvement. "involvement is a state of interest, motivation or arousal" (Rotschild, 1984). 
Involvement towards the product is defined as a perceived personal interest for the product from a given consumer (Celsi and Olson, 1988). It influences the consumer's behaviour (Flynn and Goldsmith, 1999 ; Laurent and Kapferer, 1985). As regards the buying of wine, the role of involvement has been empirically validated on several occasions (Aurifeille et al., 2002; Barber, Ismail and Dodd, 2008; Lockshin and Hall, 2003; Lockshin et al., 1997; Quester and Smart, 1996, 1998). Higher involved consumers use more information and are interested in learning more, while low involved consumers tend to simplify their choices and use risk reduction strategies (Lockshin, 2003). For example, highly involved consumers place less emphasis on the price than consumers who have low involvement (Zaichkowsky, 1998) and low involved consumers tend to give importance to back label information (Barber, Ismail and Dodd, 2008). The involvement shown in the wine can also have an impact on the use or not of the "brand" attribute in a purchase (Aurifeille et al., 2002). Consumers with low involvement simplify their choice by utilizing price, label, design, grape variety and brand. By contrast, consumers with high involvement are more inclined to use complex information cues (Barber, Ismail and Dodd, 2008). Brand acts as a risk limiter and we can expect that this attribute is more relevant for consumers who have low involvement in wine, which leads us to hypothesis $\mathrm{H}_{2}$.

$\mathrm{H}_{2}$ - The involvement shown in the wine moderates the impact of the brand in the choice of the wine. The higher the involvement in the wine, the lower the brand influence on consumer.

\section{The moderating role of knowledge}

Expertise is a multi-dimensional construct resulting from familiarity with the product category - the behavioural component of expertise since it is the result of experience with the product (Alba and Hutchinson, 1987) - and knowledge of the product. It is defined as "the possession of a large body of knowledge and procedural skill" (Chi et al., 1982). Knowledge remains the most important determinant in wine consumption (Hussain, Cholette and Castaldi, 2007). It is generally thought that knowledge includes a subjective dimension - what the consumer believes he/she knows - and an objective dimension - what he/she really knows (Alba and Hutchinson, 1987; Brucks, 1985; Park et al., 1994). Subjective knowledge influences the choice of variables used to infer the wine's quality level (Aurier and N'Gobo, 1999; Dodd et alii 2005; Edward and Mort, 1991; Lockshin and Rhodus, 1993; Perrouty et al., 2004; Solomon, 1998). Among these studies, only two include a French sample. Aurier and N'Gobo (1999) explored the impact of expertise on the capacity to memorize attributes and the importance given to attributes. According to a European study, carried out with German, Austrian, British and French consumers, (Perrouty et al., 2004), the importance given to the brand varies according to the consumers' degree of expertise. For the novices, it is in fifth position whilst for the experts it is at the bottom of the classification. On the other hand, the "brand*region" interaction is the first attribute that the experts take into account. This study only presents agglomerated results. Therefore, we cannot deduce the importance that the French consumer gives to the brand but we can suppose that the brand influence depends on the subjective knowledge of wine according to previous studies (Perrouty et al. 2004). Because of the low number of empirical studies devoted to the impact of the brand and of subjective knowledge on wine-buying in a French context, it is relevant to formulate hypothesis $\mathrm{H}_{3}$.

$\mathrm{H}_{3}$ - Wine subjective knowledge moderates the impact of the brand in the choice of the wine. The higher the wine knowledge, the lower the brand influence on consumer.

\section{Methodology}

Two studies were carried out. The first one is an exploratory qualitative study while the second one is more explanatory and quantitative. 


\section{Study 1}

The first study aims at found evidence for the first research proposition $\mathrm{P}_{1}$ (in the field of wine, the representation of brand will differ between experts and consumers). In order to identify what the experts and the consumers consider as a brand in the field of wine, a qualitative study was carried out on two samples. On one hand, a sample of experts was constituted thanks to students doing a Master in Wine marketing (see Table II for the composition of expert sample) They are considered as experts because they have a good level of knowledge in wine marketing, wine business, wine law and wine production process. On the second hand a sample of "average consumer" was collected. This population is supposed to be much more heterogeneous as regards its level of expertise.

Table II - Study 1 - Sample composition

\begin{tabular}{|c|c|c|}
\hline & Sample 1 : experts sample & Sample 2 : average consumer sample \\
\hline Size & 21 & 190 \\
\hline Age & $\begin{array}{l}\text { from } 21 \text { to } 27 \\
\text { mean }=23\end{array}$ & $\begin{array}{l}\text { from } 18 \text { to } 89 \\
\text { mean }=42\end{array}$ \\
\hline Origin & $\begin{array}{l}\text { Aquitaine }: 33 \% \\
\text { Other region producing wine } \\
\text { (Burgundy, Alsace, Languedoc): } 66 \% \\
\text { Other French region : } 0 \%\end{array}$ & $\begin{array}{l}\text { Aquitaine }: 52 \% \\
\text { Other region producing wine } \\
\text { (Burgundy, Alsace, Languedoc) : } 14 \% \\
\text { Other French region : } 33 \%\end{array}$ \\
\hline
\end{tabular}

Two open questions were asked to the respondents.

Question 1: "How would you define a branded wine?" The answers highlight the consumers' and experts' representations of branded wines.

Question 2: "Can you name the branded wines that you know? Reply according to what you consider to be a branded wine" The answers give an indication of the objective level of knowledge towards the wine, for experts and consumers.

The corpus was then subjected to a manual thematic analysis.

\section{Study 2}

The purpose of this second study (quantitative study) is to found evidence for hypothesis $\mathrm{H}_{2}$ (the moderating role of the consumer's implication on the importance granted to the brand during the choice of the wine) and $\mathrm{H}_{3}$ (the moderating role of the consumer's expertise on the importance granted to the brand).

A questionnaire was given out to the sample of consumers described above $(n=190)$. The consumption frequency was measured by a nominal scale with four categories: non consumer; very occasional consumer (less than once to twice a week); occasional (once to twice a week) and regular (every day or almost). In terms of knowledge, a subjective measure was used in accordance with the conclusions of Flynn and Goldsmith (1999). Respondents expressed their knowledge through 4 items reflecting a general feeling of knowledge, expertise in comparison to others and familiarity with wine (Korchia, 2004). Involvement in wine was measured by a four-item scale inspired by the brand interest scale developed by Korchia (2004), Table III. This scale initially developed for the brand is suitable since it is applied to wine. A single item of the 8 had to be discarded. The «involvement» and «knowledge » dimensions provide satisfactory internal reliability. 
Table III - Wine interest and knowledge measurement scale

\begin{tabular}{|c|c|c|c|}
\hline & \multicolumn{2}{|c|}{ Factor } & \multirow{2}{*}{ Cronbach } \\
\hline & $\begin{array}{l}\text { Know- } \\
\text { ledge }\end{array}$ & $\begin{array}{c}\text { Invol- } \\
\text { vement }\end{array}$ & \\
\hline $\begin{array}{l}\text { In your opinion, what is your level of knowledge of wines in } \\
\text { general? }(1=\text { non-existent } ; 4=\text { excellent })\end{array}$ & 0.904 & & 0.92 \\
\hline $\begin{array}{l}\text { Compared to the average consumer, would you say that your } \\
\text { knowledge of wine is }((1=\text { non-existent } ; 4=\text { excellent })\end{array}$ & 0.904 & & \\
\hline $\begin{array}{l}\text { I am familiar with wine. }(1=\text { totally disagree; } 4=\text { totally } \\
\text { agree })\end{array}$ & 0.879 & & \\
\hline $\begin{array}{l}\text { I know wine very well. }(1=\text { totally disagree; } 4=\text { totally } \\
\text { agree) }\end{array}$ & 0.815 & & \\
\hline $\begin{array}{l}\text { I would like to know more about wine. }(1=\text { totally disagree; } \\
4=\text { totally agree })\end{array}$ & & 0,985 & 0.92 \\
\hline $\begin{array}{l}\text { Wine is a product that interests me. }(1=\text { totally disagree; } 4= \\
\text { totally agree) }\end{array}$ & & 0,865 & \\
\hline $\begin{array}{l}\text { I am curious about wine. }(1=\text { totally disagree; } 4=\text { totally } \\
\text { agree })\end{array}$ & & 0,831 & \\
\hline
\end{tabular}

The influence of the brand when buying wine was measured by an item ("The presence of a brand on the label could positively influence my choice") for which the respondents had to indicate their degree of agreement on a 1 (totally disagree) to 4 (totally agree) scale.

A cluster analysis including the variables of interest, knowledge, consumption frequency and age was carried out in order to identify the consumer segments where the brand has the greatest influence. We took a three-stage clustering approach, according to Cannon and Perreault (1999), and Homburg, Jensen and Krohmer (2008) procedures. The three core issues in clustering are 1) determining the number of clusters, 2) assigning observations to clusters, and 3) assessing the stability of cluster assignments.

\section{Results of Study 1: the specificity of the wine brand concept}

The thematic analysis of the first question (How would you define a branded wine?). enables us to clarify the brand notion in the minds of experts and consumers.

For the experts (sample 1), five associations emerge. They represent the core meanings of what wine represents in the minds of consumers. A branded wine is:

(1) A wine with constant quality (43\% of respondents)

The experts associate a branded wine with a "wine which has a constant quality over time" or with "regular quality".

(2) A wine characterized by a strong marketing approach (28 \%)

The marketing approach can concern the packaging, the communication, the distribution and the merchandising: "easy to pick out on the shelves [...] same marketing tools as spirits"; "it is a wine which is easy to pick out in the shop because it has strong identifying characteristics"; "a wine which is well distributed, present in shops and in the media, with well thought-out and sophisticated packaging and a simple and suggestive name".

(3) A standard wine (24\%)

A branded wine, according to the experts, refers to the "standardization of the product"; to "a standard quality wine", "democratic", and "not very complex". It "goes against the terroir".

(4) A wine made by a merchant (24\%)

A branded wine is closely associated with a merchant's wine resulting from blending. 


\section{(5) A mass-produced wine $(9.5 \%)$}

To a lesser extent, the experts associate branded wines with high-volume production. attribute:

In the minds of the other group $(\mathrm{n}=190)$, a branded wine is defined by four types of

(1) A wine whose origin is known: terroir and appellation (26 \% of respondents), château, estate ( $23 \%$ )

The brand serves to identify the origin of the product, either through the producer (estate, château) or a region of production, a terroir. .

(2) A wine whose reputation is well established (22\%)

The respondents associate the branded wine with "a wine which is known and recognized" and with "reputation".

\section{(3) A wine with high perceived quality (17\%)}

According to the respondents, a branded wine is a quality wine. Quality is expressed both in gustatory terms ("a wine with a nice taste") and also in more objective terms in as much as the wine is certified by recognized specialists ("A recognized wine : experts and the general public" "A wine with a medal") or through labels ("A branded wine is one which follows quality criteria such as the A.O.C.").

\section{(4) A wine with a powerful and prestigious image (5.3\%)}

Branded wines, as seen by consumers, also benefit from a distinctive and prestigious image: "wine which has character and stands out from others"; "wine which is almost unique in terms of taste and history"; "prestige"; "a wine which you cannot be indifferent to, which gently stimulates your taste buds".

In conclusion, two elements are apparent. On one hand, branded wines represent different things in the minds of consumers than in those of experts. For the group described as experts, the wine brand conjures up associations with "marketed wines". It is a narrow vision when compared with that of the sample of consumers. For the latter, the perceived quality is relatively high, whilst for the experts it is seen as simply standard or constant. According to the consumers, the brand enables us to identify the origin of the wines - terroir or producer whilst for the experts it is essentially a question of blended or merchants' wines whose producer cannot be identified. Finally, for consumers, branded wines are known and recognized. They have a high awarenes value. The constant quality, their standard character and the association with a merchant's wine are referred to by consumers but in a far lower proportion than by experts. These answers probably come from expert consumers who refer to "marketed wines".

The analysis made on the second question (name some wine brands) enables us to go further in terms of how a consumer describes a wine brand. Table IV shows the results of the reclassifications carried out on the answers to this open question (reorganisation of the answers into 6 categories indicated in the table below).

Table IV - Classification of branded wines named

\begin{tabular}{|c|c|c|c|c|}
\hline \multirow[b]{2}{*}{ Catégories $\unrhd$} & \multicolumn{2}{|c|}{$\begin{array}{l}\text { Total answers } \\
\text { Sample } 1+2\end{array}$} & \multirow{2}{*}{$\begin{array}{c}\text { Sample 1 } \\
\text { Expert } \\
\text { students } \\
\mathrm{N}=21 \\
\text { Relative } \\
\text { frequency }\end{array}$} & \multirow{2}{*}{$\begin{array}{c}\text { Sample } 2 \\
\text { Consumers } \\
\mathrm{n}=190 \\
\text { Relative } \\
\text { frequency }\end{array}$} \\
\hline & $\begin{array}{l}\text { Absolute } \\
\text { frequency }\end{array}$ & $\begin{array}{l}\text { Relative } \\
\text { frequency }\end{array}$ & & \\
\hline Origin : $A O C$, terroirs, regions & 530 & 54.8 & 0 & 64.6 \\
\hline Names of châteaux & 179 & 18.6 & 0 & 20.6 \\
\hline Commercial brands (stricto sensu & 174 & 18 & 88 & 9.8 \\
\hline
\end{tabular}




\begin{tabular}{lcccc}
\hline branded wines) & & & & \\
\hline merchant wines & 37 & 3.8 & 9.5 & 2.4 \\
\hline Grape varieties & 27 & 2.8 & 0 & 2 \\
\hline Foreign wines & 20 & 2 & 2.5 & 0.6 \\
\hline Total & 967 & 100 & 100 & 100 \\
\hline
\end{tabular}

The analysis of the content clearly shows that the notion of the brand in the minds of the consumers does not correspond to what we commonly agree to call a brand and what experts consider as a brand. The A.O.C.s make up $64.6 \%$ of the answers given as supposed names of brands. They are followed by names of châteaux. Brands in the strict sense represent less than 10 percent of the answers given by consumers while they represent 88 percent for experts.

What can appear at first sight as confusion in the minds of consumers enables us to highlight three elements. Firstly, the brand in the wine field is a cluster of attributes. It takes on a more complex character than in other areas of consumption. Secondly, what the consumer names as a wine brand (region, appellation, château) possesses all the characteristics of a brand in the "marketing" sense of the term. Therefore it is appropriate to talk of a "region equity" (Orth et al., 2004) and of a "château equity" which become key elements upon which the players in this sector must base their sales efforts. These attributes function as a brand and act upon consumers' buying decisions. Equally, if confusion is great for the large majority of respondents, it remains absent for the group defined as experts.

Based on the results of the qualitative survey, it is possible to clarify the brand notion in the wine context. We could represent the different brands of wine in two ways: a) the assumed quality associated with the brand (high $v s$. low) and b) the level of expertise in wine (experts $v s$. average consumers). Thanks to this distinction, three levels of wine brands appear (figure 1) which represent different degrees of brand concepts applied to the word of wine: wine brands, branded wines and lastly stricto sensu branded wines (or «marketed » wines). These three levels of wine brands are associated with very different product attributes, as shown in figure1.

The first level corresponds to the consumer perceptions (wine brands). This is the most heterogeneous representation which gathers all the elements considered as brands by the consumer. Within this level of representation, we can therefore include, for example, the origin, the grape variety and the «château » term.

The second one is the branded wines representation which is close to the legal notion of the viti-cultural brand. This category includes brands created by merchants, vins de pays with a brand name and retailers' own label brands, for example. These names have to possess a high level of consumer awareness and a good image in order to play the full role of the brand in the eyes of the consumer.

The third degree is the experts' representation of branded wines. It is made up of «marketed» wines or stricto sensu branded wines. These can be defined as blended wines made in cellars by merchants or by other producers (for example, wine cooperatives), sold under powerful brand names, targeting constant and standard quality and produced on a large scale. In our empirical study, the experts' notion corresponds more closely to the definition of the stricto sensu branded wine. 


\section{Figure 1.}

Representations of brands in the French wine context

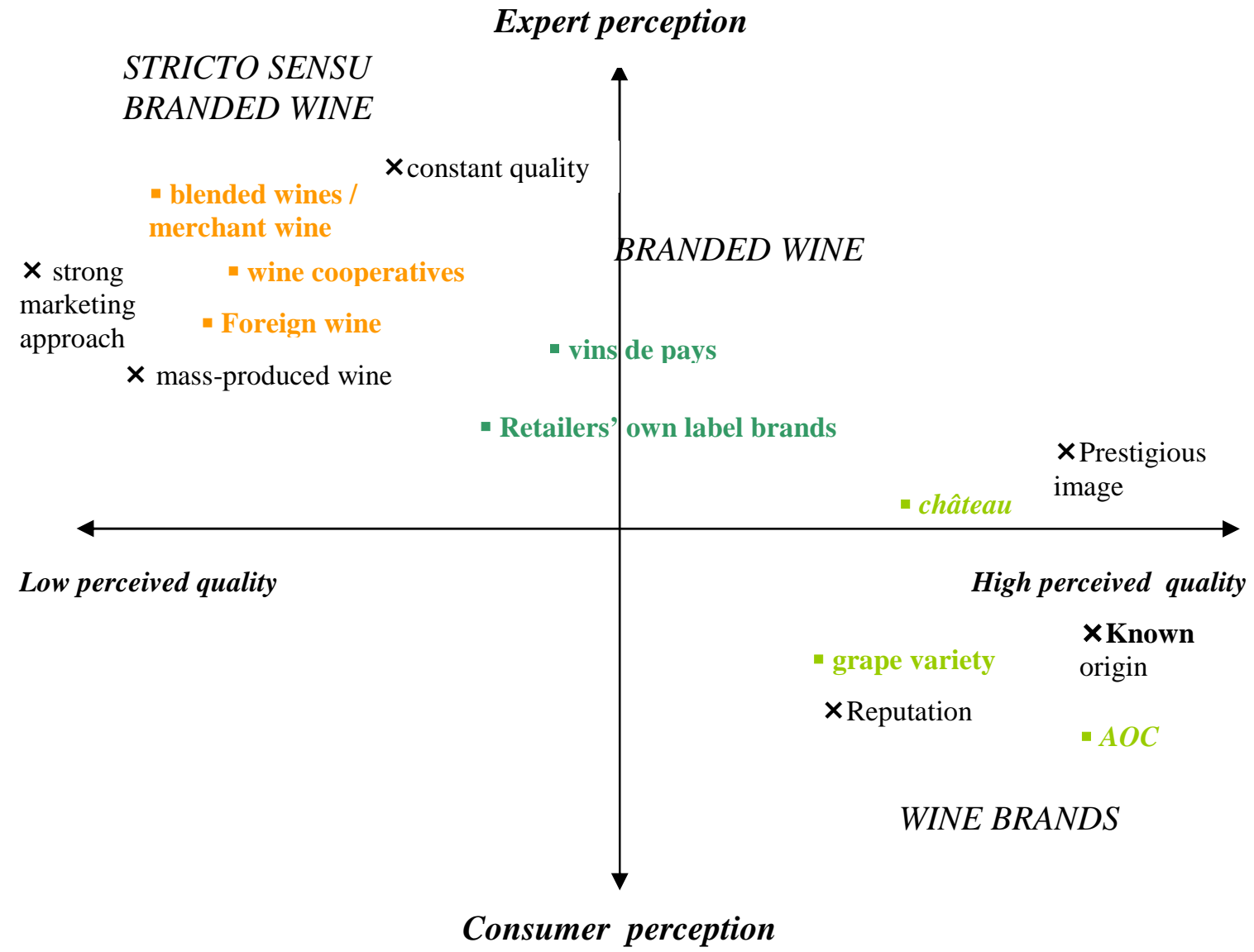

\section{Result of Study 2: the role of the brand in the wine buying process}

To perform the cluster analysis, people who declare not buying and not consuming wine were discarded from the sample. Only 177 responses were used. To begin with, a graphic analysis (hierarchical classification) is carried out to determine the number of clusters. Thanks to this analyse, four groups are identified. The measure used is the square of the Euclidian distance with Ward's aggregation method. The dendrogram displays the existence of four distinct groups. Finally, clustering 20 randomly selected sub samples from the data, each containing two-thirds of the sample, we found strong support for a four-cluster solution.

In the second stage, a dynamic cluster analysis (Diday, 1973; Diday, 1993) was carried out in order to specify the profile of the groups and in order to assign observations to clusters (Table IV). Dynamic cluster analysis is equivalent to K-means method used by Homburg, Jensen and Krohmer (2008) according to Jourdan and Jolibert (2006, p. 371).

Tableau IV - Cluster analysis

\begin{tabular}{|c|c|c|c|c|c|c|}
\hline & \multicolumn{4}{|c|}{ Class } & \multicolumn{2}{|c|}{ F Test } \\
\hline & $\begin{array}{c}\text { Novice } \\
\text { consumers }\end{array}$ & Discoverers & $\begin{array}{c}\text { Routine } \\
\text { consumers }\end{array}$ & $\begin{array}{c}\text { Expert } \\
\text { consumers }\end{array}$ & $F$ & Stat. sign. \\
\hline $\begin{array}{l}\text { Consumption } \\
\text { habits }\end{array}$ & $\begin{array}{l}\text { Less than } 1 \text { to } \\
2 \text { times per } \\
\text { week }\end{array}$ & $\begin{array}{l}1 \text { to } 2 \text { times } \\
\text { per week }\end{array}$ & $\begin{array}{l}1 \text { to } 2 \text { times } \\
\text { per week }\end{array}$ & $\begin{array}{l}\text { Every day or } \\
\text { almost }\end{array}$ & 36,47 & $<0.001$ \\
\hline
\end{tabular}




\begin{tabular}{lcccccc}
\hline $\begin{array}{l}\text { Average } \\
\text { knowledge of } \\
\text { wine }\end{array}$ & 1.38 & 2.36 & 2.44 & 3.09 & 134,91 & $<0.001$ \\
\hline $\begin{array}{l}\text { Average } \\
\text { involvement in } \\
\text { wine }\end{array}$ & 1.85 & 3.32 & 2.45 & 3.70 & 87,45 & $<0.001$ \\
\hline Age & $30-45$ & $18-29$ & More than 45 & More than 45 & 63,47 & $<0.001$ \\
\hline $\begin{array}{l}\text { Percentage of } \\
\text { respondents }\end{array}$ & 16,5 & 30 & 30 & 23,5 & - & - \\
\hline
\end{tabular}

Finally, to asses the stability of cluster assignment, we randomly split the sample in halves and perform a discriminant analysis. This analysis involves deriving the linear combination(s) of the independent variables that will discriminate best between the a priori defined groups, that is to say, novice consumers, routine consumers, discoverers and expert consumers. In discriminant analysis, independent variables are multiplied by their corresponding weight and these products are added together. The result is a discriminant score for each individual. The average of these discriminant scores within a particular group is referred as centroid. The first sub sample was used to identify the discriminant function(s) and determine the centroids. Then, each object in the second half were assigned to the nearest cluster centroid obtained from the first half. As a result, we obtained four cluster assignments for each object. The cross-validation indicates that 96.6 percent observations were correctly assigned. More over, 94 percent of non-selected observations were correctly assigned. Thus the stability of the cluster assignment is demonstrated.

The first class is made up of very occasional consumers (they drink wine less than 1 or 2 times per week), whose knowledge and involvement in wine is the lowest. These are novice consumers. They are between 30 and 45 years old.

The second group comprises young, occasional consumers (they drink wine 1 or to times per week), aged between 18 and 29. Their knowledge of wine is average but their involvement in it is high. These are discoverers who would like to become expert consumers (they wish to know more about wine).

The third class gathers together occasional consumers who are more than 45 years old. Their knowledge of wine is relatively high and their involvement in it is average compared to discoverers and experts. These are routine consumers.

Finally, the last group is dominated by expert, regular consumers of wine (they drink wine every day or almost) and are more than 45 years old. It is in this group that knowledge of wine and involvement in it are the greatest.

A one-way ANOVA was then conducted to compare the influence of brand between the four clusters. Even thought the brand influence is stronger for less knowledgeable consumers $(m=2.73$ for novices; $m=2.78$ for discoverers) compare to more knowledgeable one $(m=2.67$ for routine consumers; $m=2.67$ for experts), the differences are not statistically significant $\left(\mathrm{F}_{3}\right.$; $163=0,229, \mathrm{p}>0.05)$. More over, the brand influence is stronger for discoverers while their involvement in wine is higher compared to the novice or to the routine consumers.

We decided to split the sample in three parts as regards to wine subjective knowledge: low ( $n=46$; subjective knowledge $<2)$, average $(n=62$; subjective knowledge between 2 and 2.75) and high knowledge ( $\mathrm{n}=66$; subjective knowledge > 2.75). The average level of subjective knowledge was 2.39 and the standard deviation 0.73. A new one- way ANOVA was carried out in order to compare the brand influence between the three groups. The brand influence is stronger for the low knowledgeable group $(\mathrm{m}=2.98)$ and weaker for the high knowledgeable group $(m=2.2)$. The difference between the "low knowledge" group and the "high knowledge" group as well as the difference between the "average knowledge" group $(\mathrm{m}=2.93)$ and the "high knowledge" group are significant $(\mathrm{p}<0.05)$. Thus, hypothesis $\mathrm{H}_{2}$ (the 
involvement shown in the wine moderates the impact of the brand in the choice of the wine: the higher the involvement in the wine, the lower the brand influence on consumer) is partially supported.

Finally, the same procedure was used to compare brand influence between low, average and high involvement groups but none of the differences were significant. Thus $\mathrm{H}_{3}$ (Wine subjective knowledge moderates the impact of the brand in the choice of the wine. The higher the wine knowledge, the lower the brand influence on consumer) is not supported.

\section{General discussion and conclusion}

What emerges from the first study is that experts and consumers have different representations of brand in the field of wine. Experts consider that only standard massproduced "marketed wines" made by wine merchants are branded wines while, in consumers" mind, wine brands are associated to high quality, prestige, reputation and awareness. More over, the brand concept is not clearly perceived by the consumer: there is confusion between the brand and the A.O.C. Several factors account for this confusion. Firstly, certain A.O.C. wines are price-positioned very closely to marketed wines (between 1.5 and 2.5 euros). However, the A.O.C. alone does not suffice to sell a wine. Spared until 2004, this segment has been affected by the crisis since then. With its 450 appellations, what it offers is often considered complex whilst the vins de pays, with greater room for manoeuvre, have introduced marketing strategies designed to simplify what they sell. For example, Boire et Manger is a range of wine with colourful packaging which suggest which dishes go with the wines (fish, lamb or poultry). Secondly, certain practices foster confusion between brand and château. Many châteaux sell branded wines. A novice consumer could easily confuse a Mouton Cadet with a Château Mouton Rothschild. Certain brands make multiple references to our imagination of life in the château through the name (Baron de Lestac, anagram of Castel), in the packaging (château de Cadillac on the label of the Les hauts de Lestac wine) or in commercial communication (joint advertising of the Cellier des Dauphins brand and of Château de Rochegude, Relais et Château de la Drome) and maintain this confusion.

The second study shows that the brand is probably an appropriate response to certain consumer segments although our results are not statistically significant. This can be first explained by the measure of brand influence we used in the quantitative study. This was an influence expressed by the respondents and not the direct measurement of behaviour. A second explanation of this result concerns what each group of consumer (novice or expert) considers as a wine brand. More over, it is according to what she/he considers as a brand that each respondent has answered this question. The qualitative study has shown that the consumer has a very broad perception of the brand notion. Experts and novice consumers are probably not influenced by the same branding strategy. The study 1 shows that consumers are sensitive to awareness, reputation and prestige. For the novice consumers, perhaps AOC, regions, "châteaux" are more able to reach these characteristics than wine merchants' brands, except some well known brands like "Mouton Cadet". If producers and wine merchants want to convince consumers to buy branded wines, they have to capitalize on existing brands or to create new strong brands. More over, the cluster analyse reveals the existence of an interesting class of wine consumers "the discoverers". They are young "emerging wine learners" coming from the novices group. They declare to be positively influenced by brands. It's important to differentiate novice consumers from discoverers because they tend to be sensitive to more complex attributes, traditionally used by the experts, like origin, vintage and production (Barber, Ismail and Dodd, 2008).

For several years, brands have been presented as a miracle solution to enable the French wine industry to escape from the crisis. Has this happened? We must bear in mind that the fall in wine consumption in France is a structural phenomenon (70 litres per inhabitant per year in 
2005 compared to 160 in 1965). Brands alone cannot reverse this trend. However, our results can help producers in defining brand strategies. Here is a five-point answer.

1. French wine making is closer to a craft than an industrial process while high production volumes are necessary to hope to recoup the investments needed to develop a brand. Often, small producers have to be brought together before a genuine marketing approach can be embarked upon.

2. The development of powerful brands should not be to the detriment of the consumer's expectations in terms of quality and price. In 2008, the average price paid in France was 2.99 euros per litre (VINIFLHOR, 2008b). The qualitative study shows that even if consumers have difficulties naming branded wines, they have a very clear view of the qualities that they should possess. It must be "a wine whose quality is known and recognized" (Study 1). Quality and awareness are two determinants of brand equity (Aaker, 1996). In this respect, wine is the same as other product categories: the brand should reassure the consumer. It is unlikely that consumers will be satisfied with a wine with merely an image.

3. Producers and merchants must focus on range brands which reduce marketing investments, facilitate a change in attitude towards new products and strengthen consumer awareness of the brand equity. This is, for example, the strategy followed by the Grands Chaix de France with the JP Chenet brand. The same brand name is used to sell different wines all around the world. In a longitudinal study, Wilcox et al. (2008) found a positive relationship between brand equity (brand recognition and perceived quality) and probability of brand survival. A stretched brand is more able to match consumer awareness and, thus, to survive.

4. Co-branding strategies must be given top priority in order to reassure the consumer. Several types of wine-specific alliances can be envisaged. The brand/name of merchant alliance is desirable if the merchant group has a good reputation. The Cordier firm, for example, puts its name on most of its wines: Collection privée, Agathe, Prestige and Terres d'Héritage. The brand/origin alliance is particularly interesting given that these two attributes are closely linked in the mind of the consumer. The origin/brand interaction is certainly an asset to be exploited for both the vins de pays and the A.O.C. The origin provides an extra guarantee. In this alliance, the place/region equity and the brand equity interact to strengthen the product image. For example, Bordeaux can play such a role. The brand/grape variety/origin alliance can also serve as a guarantee. Although grape variety is traditionally considered as a secondary attribute in France, it must not be neglected given the healthy state of the varietal vins de pays segment $(+18.3 \%$ in value and $+17.8 \%$ in volume in 2007), (VINIFLHOR, 2008a). In this category, red wines (Merlot and Cabernet Sauvignon grape varieties) make up the greatest market share $(61 \%)$ with an increase of $24 \%$ in 2007 . But rosé varietal vins de pays (with a $21 \%$ market share) are also enjoying growing success: + $27.5 \%$ in volume for Cinsault and $+19.8 \%$ for Grenache. This is another way to strengthen brand equity.

5. Finally, the brand can provide an appropriate response to certain consumer segments, especially to discoverers. New brand names convey a semantic change and show a willingness to stand out from the field of the château: E-motifs, Le flacon, Virginie de France, «Maestral, L'infernal and Tandem by DP. It is not sure that breaking existing codes is desirable for traditional consumers and for neo consumers (author, 2009). This remark is also applicable to the foreign consumer. When she/he buys a French wine, she/he is probably looking for one which is typical of this category rather than a wine which appears closer to a New World one because of its packaging. The branded wines which have the best sales in France are those which « copy » château wines in terms of design and packaging.

In conclusion, this research has certain limits which constitute paths to improvement. Firstly, the influence of the brand has been considered as an isolated attribute and from the 
brand name point of view. In reality, the brand is an attribute among others and we need to add other attributes, by using, for example, a conjoint analysis or an information display board to better understand the importance of the brand in the choice of a wine compared to other cues like intrinsic cues, aesthetic cues and packaging and information on back label, for example. Such a method would allow to by-pass the declarative measure of brand influence used in this research.

Secondly, the changes in the French market are not restricted to purely quantitative aspects. The occasions when wine is drunk are also changing (Aurier, 2004). The image of wine as a drink accompanying daily meals is in sharp decline - when it is associated with a meal, it is essentially for a festive or a weekend one - and new occasions when wine is drunk are developing (apéritif and a moment of relaxation with friends). The influence of the brand can vary according the occasion.

Finally, it would be appropriate to explore the attraction of French branded wines for international consumers. When they buy a French wine, are they attracted by a branded wine or by one which respects the traditional codes?

\section{References}

Aaker D. (1996), Building strong brands, The Free Press.

Alba, J. W. and Hutchinson J. W. (1987), "Dimensions of Consumer Expertise, Journal of Consumer Research", Vol.13 March, pp. 411-454.

Aurier, P. (2004), "Consommation du vin en France : une analyse à partir des contextes de consommation", in Bacchus 2005 - Enjeux, stratégies et pratiques dans la filière vitivinicole, ed. d'Hauteville, F., Couderc, J.-P., Hannin, H. and Montaigne, E., Dunod, Paris.

Aurier, P. and N'Gobo, P. (1999), "Assessment of Consumer Knowledge and its Consequences: A Multi-Component Approach", in Advances in Consumer Research, 26 ed.UT: Association for Consumer research, pp. 569-575.

Aurifeille, J. M., Quester, P. G., Hall J. and Lockshin, L. (1999), "Investigating situational effects in wine consumption: a means-end approach", in European Advances in Consumer Research, Vol. 4, pp. 104-111.

Aurifeille, J. M., Quester, P. G., Lockshin, L. and Spawton, T. (2002), "Global vs International involvement-based segmentation: a cross national study", International Marketing Review, Vol. 19 No. 4, pp. 369-386.

Barber N., Ismail J. and Dodd T. (2008), "Purchase attribute of wine consumers with low involvement", Journal of Food Products Marketing, Vol. 14, No 1, pp. 69-86.

Belik, W., dos Santos, R. R. and Green, R. (2001), "Food Retailing, Quality Signals and the Customer Defence", in World Food and Agribusiness Symposium of the International Food and Agrobusiness Management Association, Sidney, Australia.

Bomsel O. (2003), "Vin, produit et information", CERNA, Paris.

Boulet, D. and Laporte, J. P. (1997), "Les comportements de consommation de vin en France", Recherches en Economie et sociologies rurales, INRA, Sciences Sociales, Vol.10 No. 3.

Brucks, M. (1985), "The effect of product class Knowledge on information search behavior”, Journal of Consumer Research, Vol. 12 No. 1, pp. 1-16.

Cannon, J.P., and Perreault W.Jr (1999). "Buyer-Seller Relationships in Business Markets", Journal of Marketing, Vol. 36 (November), pp. 439-60.

Celsi, R. and Olson, J. (1988), "The role of involvement in attention and comprehension processes", Journal of Consumer Research, Vol. 15 September, pp. 211-224.

Chi, M., Glaser, R. and Rees, E. (1982), "Expertise in problem solving", in Sternberd, K. J. (ed.), Advances in The Psychology of Human Intelligence, Vol. 1, Hisdale, NJ: Laurence Erlbaum Associates. 
D'Hauteville F. (2004), "Un nouveau regard sur les enjeux et les stratégies dans la filière vitivinicole”, in Bacchus 2005 - Enjeux, stratégies et pratiques dans la filière vitivinicole, ed. d'Hauteville, F., Couderc, J.-P., Hannin, H. and Montaigne, E., Dunod, Paris, pp. III-VIII.

Diday E. (1973), "The dynamic cluster method and sequentialization in non hierarchical clustering", Rapport de recherche INRIA, No 26.

Dodd, T. H., Laverie, D. A., Wilcox, J. F. and Duhan, D. (2005), "Differential effects of experience, subjective knowledge and objective knowledge on sources of information used in consumer wine purchasing", Journal of Hospitality and Tourism Research, Vol. 29 No. 1, pp.3-19.

Edward, F. and Mort, G. (1991), "The expert wine taster", Journal of Wine Marketing, Vol. 3 No. 1, pp. 9-44.

Flynn, L. R. and Goldsmith, R. E. (1999), “A Short, Reliable Measure of Subjective Knowledge", Journal of Business Research, Vol. 46, pp. 57-66.

Gherbi, T. (2004), "Marques et foires de vin", Colloque CEnométrie XI, Dijon.

Gluckman, R. L. (1990), "A consumer approach to branded wines", European Journal of Marketing, Vol. 20 No. 6, pp. 21-35.

Holter, G. (1996), "Listening to the brand", Off Licence News, Vol. 7, No. 10.

Homburg, Christian, Ove Jensen, and Harley Krohmer (2008). "Configurations of Marketing and Sales: A Taxonomy", Journal of Marketing. Vol. 72 (March), pp 133-154.

Hussain M., Cholette S. and Castaldi R. (2007), "Determinants of wine consumption of US consumers, an econometric analysis", International Journal of Wine Business Research, Vol.19, No 1, pp 49-62.

Jacoby, J. and Kaplan, L. B. (1972), "The components of perceived risk", in Venkatesan, M. (ed.) Advances in Consumer Research, Chicago, pp. 382-393.

Jourdan P. and Jolibert A. (2006), "Marketing Research", Dunod, Paris.

Koewn, C. and Casey, M. (1995), "Purchasing behaviour in the Northern Ireland wine market", British Food Journal, Vol. 97, No. 11, pp. 17-20.

Korchia, M. (2004), "The Effects of Brand Associations on Three Constructs", Proceedings from the 30th EMAC Conference, Murcia, Spain.

Laurent, G. and Kapferer, J. N. (1985), "Measuring consumer involvement profiles", Journal of Marketing Research, Vol. 22, pp. 41-53.

Lockshin L. (2004), "La marque et le vin", in Bacchus 2005 - Enjeux, stratégies et pratiques dans la filière vitivinicole, ed. d'Hauteville, F.; Couderc, J.-P., Hannin, H. and Montaigne, E., Dunod. Paris, pp. 210-225.

Lockshin, L. S. and Hall, J. (2003), "Consumer Purchasing Behaviour for Wine: what we know and where we are going", working paper.

Lockshin, L. S. and Rhodus, W. T. (1993), "The effect of price and oak flavour on perceived wine quality", International Journal of Wine Marketing, Vol. 5 No. 2, pp.13-25.

Lockshin, L. S., Spawton, T. and Machintosh, G. (1997), "Using product, brand and purchasing involvement for retail segmentation", Journal of Retailing and Consumer Services, Vol. 4 No. 3, pp. 171-183.

Mazé, A., Polin, S., Raynaud, E., Sauvée, L., and Valceschini, E. (2001), "Quality signals and governance structures within European agro-food chains: a new institutional Economics approach", Economics of contract in Agricultureand Food Supply Chain-EAAE Seminar, 78, Copenhagen.

Mc Cutcheron E., Bruwer J. and Li E. (2009), "Region of origin and its importance among choice factors in the wine-buying decision making of consumers", International Journal of Wine Business Research, Vol. 21, No 3, pp. 212-234.

Mora, P. (2008), "Les vins de marque", Dunod, Paris. 
O.N.I.V.I.N.S., (2003) Le vin, l'achat, la confiance et la marque: le cas du consommateur français, O.N.I.V.I.N.S. Info, No. 105, July-August.

Orth, U., McGarry, M., Dodd, T. H., Quagliano, J. and Van Westering, J. (2004), "Place-Based Marketing Strategies: A Cross-national Perspective for Wine", working paper, College of Business - Oregon State University.

Park, C. W., Motherbaugh, D. L. and Feick, L. (1994), "Consumer Knowledge Assessment", Journal of Consumer Research, Vol. 21 No. 1, pp. 71-82.

Perrouty, J., d'Hauteville, F. and Lockshin, L. (2004), "Impact des interaction entre marques et régions d'origine sur la valeur perçue d'un vin : proposition de prise en compte de

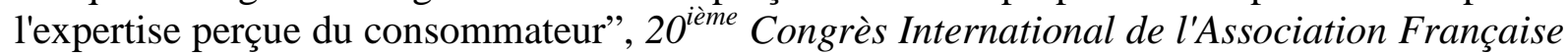
de Marketing, Saint-Malo.

Quester, P. G. and Smart, J. (1996), "Product involvement in consumer wine purchases: its demographic determinants and influence on choice attributes", International Journal of Wine Marketing, Vol. 8 No. 3/4, pp. 37-56.

Quester, P. G. and Smart, J. (1998), "The influence of consumption situation and product involvement over consumers' use of product attributes", Journal of Consumer Marketing, Spring, pp. 220-238.

Rasmussen, M. and Lockshin, L. (1999), "Wine choice behaviour: the effect of regional branding", International Journal of Wine Marketing, Vol. 11 No. 1, pp. 36-46.

Roselieus, T. (1971), "Consumer ranking perceived risk: conceptualisation and models", European Journal of Marketing, Vol. 35 No. 1, pp. 56-61.

Rotschild, M. L. (1984), "Perspectives on involvement: current problems and future directions", in Association for consumer research, 1 ed. Ann Arbor, pp. 216-217.

Solomon, G. (1998), "Psychology of novice and expert wine talk", American Journal of Psychology, Vol. 103 No. 4, pp. 495-517.

Sylvander, B., Allaire, G., Belletti, G., Marescotti, A., Barjolle, D., Thévenondmottet, E. and Tregear, A. (2005), "Les dispositifs français et européens de protection de la qualité et de l'origine dans le contexte de l'OMC : justifications générales et contextes nationaux", Symposium international Territoires et enjeux du développement régional, Lyon.

VINIFLHOR (2008a), "Les ventes de vins tranquilles en grande distribution, Bilan annuel 2007”, Viniflhor Infos, No. 152, April, Tome I.

VINIFLHOR (2008b), "Les achats de vins tranquilles par les ménages français pour leur consommation à domicile - Campagne 2007-2008”, Viniflhor Infos, No. 157, October.

Wilcox J. B., Laverie D. A., Kolyesnikova N., Duhan D. F. and Dodd T. H. (2008), "Facets of brand equity and brand survival - a longitudinal examination", International Journal of Wine Business Research, Vol. 20, No 3, pp. 202-213.

Zaichkowsky, J. (1985), "Measuring the involvement construct", Journal of Consumer Research, Vol. 12, pp. 341-352. 